\title{
Molecular cloning and expression analysis of peptidase genes in the fish-pathogenic scuticociliate Miamiensis avidus
}

\author{
Jung Soo Seo ${ }^{1}$, Eun Ji Jeon' ${ }^{1}$ Sung Hee Jung ${ }^{1}$, Myoung Ae Park' ${ }^{1}$ Jin Woo Kim², Ki Hong Kim³ , Sung Ho Woo ${ }^{4}$ \\ and Eun Hye Lee 1* $^{*}$
}

\begin{abstract}
Background: Parasite peptidases have been actively studied as vaccine candidates or drug targets for prevention or treatment of parasitic diseases because of their important roles for survival and/or invasion in the host. Like other parasites, the facultative histophagous ciliate Miamiensis avidus would possess peptidases that are closely associated with the invasion into the host tissue and survival in the host.

Results: The 17 genes encoding peptidases, including seven cathepsin-like cysteine peptidases, four serine carboxypeptidases, a eukaryotic aspartyl protease family protein, an ATP-dependent metalloprotease FtsH family protein, three leishmanolysin family proteins and a peptidase family M49 protein were identified from a Miamiensis avidus CDNA library by BLAST X search. Expression of genes encoding two cysteine peptidases, three leishmanolysin-like peptidases and a peptidase family M49 protein was up-regulated in the cell-fed ciliates compared to the starved ciliates. Especially, one cysteine peptidase (MaPro 4) and one leishmanolysin-like peptidase (MaPro 14) were transcribed more than 100-folds in the cell-fed ciliates.
\end{abstract}

Conclusions: The genetic information and transcriptional characteristics of the peptidases in the present results would be helpful to elucidate the role of peptidases in the invasion of scuticociliates into their hosts.

Keywords: Scuticociliates, Miamiensis avidus, Peptidases, RT-PCR

\section{Background}

Parasite peptidases have been widely studied as potential vaccine candidates or promising targets of anti-parasitic agents for prevention or treatment of parasitic diseases, because of their crucial roles in completing the life cycles or diseases they produce. In many protozoan parasites that cause malaria, trypanosomiasis, leishmaniasis, amebiasis, toxoplasmosis, giardiasis, cryptosporidiosis, and trichomoniasis, the major roles of parasite peptidases include invasion by degradation of host cells and tissues, degradation of mediators of the immune responses, and the catabolism of host proteins for parasite growth and survival [1-5].

\footnotetext{
* Correspondence: lehyaho@daum.net

${ }^{1}$ Pathology Division, National Fisheries Research \& Development Institute (NFRDI), 152-1, Haean-Lo, Gijang-Up, Gijang-Gun, Busan 619-705, South Korea Full list of author information is available at the end of the article
}

In the facultative histophagous Miamiensis avidus (= synonym of Philasterides dicentrarchi), which causes high mortality in cultured olive flounder (Paralichthys olivaceus) in Korea [6,7], peptidases might play important roles in the process of transforming of the ciliates from the free-living form into the invasive, infectious form, which might make the peptidases as candidates for vaccine antigen or treatment drug target. It has been reported that peptidases secreted by Philasterides dicentrarchi can degrade type-I collagen, modulate host cellular immune responses, and induce apoptosis of leucocytes [8-11]. Moreover, $P$. dicentrarchi peptidases could affect host humoral immune responses by degrading the host immunoglobulins and reducing host complement activity in fish serum and ascitic fluid [12].

Although there are several reports about the important roles of peptidases in scuticociliate $M$. avidus, no studies combined with genetic identification of peptidase genes

\section{Biomed Central}


and gene expression related to the function on the invasion have been performed. Therefore, the purpose of this study was to identify peptidase genes that are expected to have features related to infection of $M$. avidus by comparison of expression level between the cell-fed and the starved ciliates.

\section{Methods \\ Ciliates}

Ciliates were isolated from ascitic fluid of an infected olive flounder Paralichthys olivaceus collected from a local fish farm in Korea, and were identified as Miamiensis avidus using species-specific oligonucleotide primers [6]. Chinook salmon embryo (CHSE)-214 cells, incubated at $20^{\circ} \mathrm{C}$ in Eagle's minimum essential medium (MEM, Sigma, St. Louis, Mo, USA) supplemented with $10 \%$ heat-inactivated fetal bovine serum (FBS), were used as grazing material to grow the ciliates under axenic culture conditions.

To obtain cell-free cultured ciliates, ciliates harvested from routine CHSE cell-feeding cultures were transferred to filtered sea water without any nutrient components and starved at $20^{\circ} \mathrm{C}$ for at least 1 month. To obtain cell-fed ciliates, ciliates were inoculated in sufficiently grown CHSE-214 cells in routine MEM supplemented with 10\% heat-inactivated FBS or in sufficiently grown CHSE-214 cells in filtered seawater supplemented with $10 \%$ heatinactivated FBS or were intraperitoneally injected into olive flounder. The ciliates from different culture conditions were harvested using a method described previously [13]. Briefly, the ciliates were harvested by centrifugation at $200 \times g$ for $5 \mathrm{~min}$, and washed more than 3 times by centrifugation at $150 \times g$ for 5 min in Hanks' balanced salt solution (Sigma) or filtered seawater. The experiments using fish and treatment of dead fish were performed in accordance with the guideline approved by Ministry for Food, Agriculture, Forestry and Fisheries.

\section{RNA preparation, CDNA library construction and expressed sequence tag (EST) analysis}

Total RNA from CHSE-cultured M. avidus was prepared using Trizol reagent (Invitrogen, Carlsbad, CA, USA) according to the manufacturer's instructions. Poly A+ RNA from the total RNA prepared from CHSE-cultured M. avidus was isolated using the Stratagene Absolutely mRNA Purification Kit (Stratagene, La Jolla, CA, USA). A cDNA library was constructed using the ZAP Express cDNA Synthesis Kit and Gigapack III Gold packing extract (Stratagene) according to the manufacturer's instructions. The titer of constructed cDNA library was $5.6 \times 10^{5}$ plaque-forming units $(\mathrm{pfu}) / \mathrm{ml}$.

The expressed sequence tags (ESTs) were analyzed by DNA sequencing of kanamycin resistant Escherichia coli clones containing cDNA fraction-harbored phagemid
(pBK-CMV) after mass excision of the lambda phage library. DNA sequencing was conducted with T3/T7 phagemid sequencing primers using an ABI3730 automatic sequencer (96-capillary, Applied Biosystems, Foster City, CA, USA) and Applied Biosystems BigDye ${ }^{\circledR}$ Terminator Cycle Sequencing Kits v3.1, in accordance with the manufacturer's recommendations. A total of 1,265 EST sequences, obtained cDNA library of $M$. avidus RNA, were analyzed by sequence comparison with previously reported sequences in the EMBL/GenBank databases using the BLAST X search program of the National Center for Biotechnology Information (NCBI). The domain search of deduced amino acid sequences was analyzed using the SMART web and the NCBI protein blast program.

\section{Real-time reverse transcriptase polymerase chain reaction (RT-PCR) of peptidase genes in Miamiensis avidus}

RT-PCR was performed to further verify the expression patterns of the isolated peptidase genes. Total RNA was isolated from cell-free cultured ciliates and cell-fed ciliates using the RNeasy Mini Kit (Qiagen, Valencia, CA, USA). Total RNA was isolated several times, and the pooled total RNA was used for cDNA synthesis. cDNA was synthesized from $1 \mu \mathrm{g}$ of total RNA using Superscript II Reverse Transcriptase and Oligo (dT) 20 primer (Invitrogen). RT-PCR was performed using Fast Start SYBR Green Master Mix (Roche, Indianapolis, IN-, USA) and 100 ng of synthesized cDNA in a $20 \mu \mathrm{l}$ reaction volume. Quantitative PCR was conducted using an iQ5 Multicolor Real-Time PCR instrument (Bio-Rad, Hercules, CA, USA), and the $\beta$-tubulin (BTU) gene was used as the internal control for normalization. Thermal cycling conditions were one cycle of $3 \mathrm{~min}$ at $95^{\circ} \mathrm{C}$ (initial denaturation) followed by 40 cycles of $10 \mathrm{~s}$ at $95^{\circ} \mathrm{C}, 10 \mathrm{~s}$ at $55^{\circ} \mathrm{C}, 20 \mathrm{~s}$ at $72^{\circ} \mathrm{C}$. The specific PCR primers for amplification of $M$. avidus peptidase genes were designed from the unique sequences obtained by analysis of ESTs using the OLIGO 5.0 software (National Bioscience) (Table 1) and the expected sizes of PCR products are listed in Table 2. The results of RT-PCR from triplicate experiments were expressed as mean Ct (Cycle threshold) values and standard deviation. The fold change in relative gene expression under the different culture conditions was determined by the $2^{-\Delta \Delta \mathrm{Ct}}$ method $[14,15] . \Delta \Delta \mathrm{Ct}$ (delta delta $\mathrm{Ct}$ ) values were calculated using an equation, where $\Delta \Delta \mathrm{Ct}=$ $\left(\mathrm{Ct}_{\mathrm{MaPro}}-\mathrm{Ct}_{\mathrm{BTU}}\right)_{\text {cell-fed }}-\left(\mathrm{Ct}_{\mathrm{MaPro}}-\mathrm{Ct}_{\mathrm{BTU}}\right)_{\text {cell-free. }}$ Significant differences of $\mathrm{Ct}$ values were determined by Paired $\mathrm{t}$-test after normalization using those of $\beta$-tubulin gene.

\section{Results}

Isolation and sequence analysis of peptidase genes from the Miamiensis avidus cDNA library

We isolated 32 clones harboring peptidase gene sequences from 1,265 EST clones of the M. avidus cDNA library and obtained 17 different peptidase gene sequences including 
Table 1 Characterization of the peptidases in Miamiensis avidus

\begin{tabular}{|c|c|c|c|c|c|}
\hline $\begin{array}{l}\text { Name of } \\
\text { clone }\end{array}$ & $\begin{array}{l}\text { Number of } \\
\text { clone }\end{array}$ & $\begin{array}{c}\text { Protein length } \\
\text { (amino acids) }\end{array}$ & $\begin{array}{c}\text { Matched proteins } \\
\text { (Species, Accession number) }\end{array}$ & $\begin{array}{c}\text { Homology } \\
\text { (E-value) }\end{array}$ & $\begin{array}{l}\text { Putative domains } \\
\text { contained }\end{array}$ \\
\hline MaPro 1 & 3 & 355 & $\begin{array}{l}\text { Cathepsin L-like cysteine protease } \\
\text { (Uronema marinum, AAX51228) }\end{array}$ & $31 \%\left(1 \times 10^{-57}\right)$ & signal sequence, 129 , peptidase $\mathrm{C} 1$ \\
\hline MaPro 2 & 2 & 346 & $\begin{array}{l}\text { Cathepsin L-like cysteine protease } \\
\text { (Uronema marinum, AAX51228) }\end{array}$ & $36 \%\left(3 \times 10^{-68}\right)$ & signal sequence, 129, peptidase C1 \\
\hline MaPro 3 & 2 & 355 & $\begin{array}{l}\text { Cathepsin L-like cysteine protease } \\
\text { (Uronema marinum, AAX51228) }\end{array}$ & $36 \%\left(2 \times 10^{-54}\right)$ & 129, peptidase C1 \\
\hline MaPro 4 & 1 & 342 & $\begin{array}{l}\text { Cathepsin L-like cysteine protease } \\
\text { (Uronema marinum, AAX51228) }\end{array}$ & $37 \%\left(1 \times 10^{-57}\right)$ & signal sequence, 129, peptidase C1 \\
\hline MaPro 5 & 1 & 342 & $\begin{array}{l}\text { Papain family cysteine protease containing protein } \\
\text { (Tetrahymena thermophila SB210, EAR82238) }\end{array}$ & $49 \%\left(2 \times 10^{-59}\right)$ & signal sequence, 129 , peptidase $\mathrm{C} 1$ \\
\hline MaPro 6 & 2 & 337 & Cathepsin B (Uronema marinum, AAR19103) & $59 \%\left(9 \times 10^{-146}\right)$ & $\begin{array}{l}\text { signal sequence, propeptide, } \\
\text { peptidase } \mathrm{C} 1\end{array}$ \\
\hline MaPro 7 & 1 & 362 (partial) & Cathepsin C (Danio rerio, AAH64286) & $37 \%\left(1 \times 10^{-57}\right)$ & peptidase C1 \\
\hline MaPro 8 & 2 & 479 & $\begin{array}{c}\text { Serine carboxypeptidase } \\
\text { (Oxytricha trifallax, AMCR01008778) }\end{array}$ & $30 \%\left(1 \times 10^{-57}\right)$ & signal peptide, peptidase S10 \\
\hline MaPro 9 & 1 & 518 & $\begin{array}{l}\text { Serine carboxypeptidase family protein } \\
\text { (Tetrahymena thermophile, XP_001031619) }\end{array}$ & $36 \%\left(3 \times 10^{-73}\right)$ & signal peptide, peptidase S10 \\
\hline MaPro 10 & 5 & 473 & $\begin{array}{l}\text { Serine carboxypeptidase S28 family protein } \\
\text { (Tetrahymena thermophile, XP_001013945) }\end{array}$ & $53 \%\left(1 \times 10^{-155}\right)$ & signal peptide, peptidase S28 \\
\hline MaPro 11 & 1 & 477 & $\begin{array}{l}\text { Serine carboxypeptidase 24-like isoform } 1 \\
\text { (Glycine max, XP_003519151) }\end{array}$ & $32 \%\left(9 \times 10^{-62}\right)$ & signal peptide, peptidase S10 \\
\hline MaPro 12 & 1 & 381 & $\begin{array}{l}\text { Eukaryotic aspartyl protease family protein } \\
\text { (Tetrahymena thermophile XP_001016313) }\end{array}$ & $48 \%\left(2 \times 10^{-107}\right)$ & Asp domain \\
\hline MaPro 13 & 1 & 283 (partial) & $\begin{array}{l}\text { ATP-dependent metalloprotease FtsH family protein } \\
\text { (Tetrahymena thermophila SB210, EAR83289) }\end{array}$ & $79 \%\left(8 \times 10^{-159}\right)$ & AAA domain, Peptidase M41 \\
\hline MaPro 14 & 4 & 731 & $\begin{array}{l}\text { Leishmanolysin family protein, putative } \\
\text { (Ichthyophthirius multifiliis, EGR31368) }\end{array}$ & $34 \%\left(1 \times 10^{-82}\right)$ & $\begin{array}{l}\text { Signal peptide, Peptidase M8, } \\
\text { EGF-like domain, Furine-like repeat }\end{array}$ \\
\hline MaPro 15 & 5 & 1102 & $\begin{array}{l}\text { Leishmanolysin family protein, putative } \\
\text { (Ichthyophthirius multifiliis, EGR31368) }\end{array}$ & $33 \%\left(1 \times 10^{-73}\right)$ & $\begin{array}{l}\text { Signal peptide, Peptidase M8, } \\
\text { EGF-like domain, Furine-like repeat }\end{array}$ \\
\hline MaPro 16 & 1 & 693 & $\begin{array}{l}\text { Leishmanolysin family protein, putative } \\
\text { (Ichthyophthirius multifiliis, EGR33997) }\end{array}$ & $29 \%\left(1 \times 10^{-64}\right)$ & $\begin{array}{l}\text { Signal peptide, Peptidase M8, } \\
\text { EGF-like domain, Furine-like repeat }\end{array}$ \\
\hline MaPro 17 & 1 & 708 & $\begin{array}{c}\text { Peptidase family M49 } \\
\text { (Tetrahymena thermophila SB210, EAR87978) }\end{array}$ & $61 \%(0)$ & Peptidase M49 \\
\hline
\end{tabular}

15 full open reading frames and two partial sequences after DNA sequencing with the T3 and T7 primers and gene specific primers. These 17 genes encoded peptidase proteins including seven cysteine peptidases, four serine carboxypeptidases, a eukaryotic aspartyl protease family protein, an ATP-dependent metalloprotease FtsH family protein, three leishmanolysin family proteins and a peptidase family M49 protein, respectively. The characteristics of the peptidase proteins, including frequency, protein length, homology to previously deposited proteins and conserved domains are shown in Table 1. The conserved domains were analyzed using the SMART web program, Genbank BLAST program, and other literature [16-22].

The seven cysteine peptidases (MaPro 1 - MaPro 7) commonly contained the peptidase $\mathrm{C} 1 \mathrm{~A}$ domain in their mature protein sequences, which contained catalytic triad residues $(\mathrm{C}, \mathrm{H}$, and $\mathrm{N})$ essential for peptidolytic activity, glutamine $(\mathrm{Q})$ residue involved in the formation of the oxyanion hole, the structurally important GCNGG motif, six cysteine residues forming three disulfide bonds and $\mathrm{S}_{2}$ subsite determining enzyme substrate specificity (Figure 1). However, in MaPro 4, both the first amino acid residue of the catalytic triad and the fifth cysteine residues forming a disulfide bond were $\mathrm{G}$, not $\mathrm{C}$. The five cysteine peptidase proteins had signal peptide sequences, except for MaPro 3 and MaPro 7 which had no detectable signal peptide and obtained partial sequence containing only the peptidase C1A domain, respectively. The conserved signatures of cathepsin L family protein, ERFNIN and GNFD motifs with slight variation were presented in the type I29 inhibitor domain of MaPro 1 - MaPro 5 proteins presented in other cathepsin L proteins. ERFNIN motif seems to function as an autoinhibitory domain [23] and an important role of GNFD motif in processing and folding of $\mathrm{C} 1 \mathrm{~A}$ proteses have been shown using site-directed mutagenesis studies [24]. Sequence identities of MaPro 1 - 
Table 2 List of primers used in quantitative reverse-transcription PCR (RT-PCR)

\begin{tabular}{|c|c|c|c|}
\hline Target clone/gene & Primers & Sequences $\left(5^{\prime}-3^{\prime}\right)$ & Product size (bp) \\
\hline \multirow[t]{2}{*}{ MaPro 1} & Forward & TGCTTCCACTTCAGTTTTATCAGTCG & 266 \\
\hline & Reverse & GGTTAAGTTCAACTGTGGGGATTTCTAA & \\
\hline \multirow[t]{2}{*}{ MaPro 2} & Forward & TCTTGAGAGCTTCTGCTGCCAC & 271 \\
\hline & Reverse & TCTTGGATGTTTAATTCGGTGCTGT & \\
\hline \multirow[t]{2}{*}{ MaPro 3} & Forward & AATCCAACGAAGACATCAGAATCTTCT & 246 \\
\hline & Reverse & CAGGGACTTATCTGGAAGGTCTGGA & \\
\hline \multirow[t]{2}{*}{ MaPro 4} & Forward & TAGCTTCAATTGCTTCTGGTAGTCTTG & 277 \\
\hline & Reverse & ATCCATGTTTATTCCACATAGTCCATTAC & \\
\hline \multirow[t]{2}{*}{ MaPro 5} & Forward & ATTTCAAGCGATTGGAAGCTAAGAATC & 308 \\
\hline & Reverse & AATAATCCCAAATAGAATATTACCCATCTTC & \\
\hline \multirow[t]{2}{*}{ MaPro 6} & Forward & ACTTGGACTGCTGGATACAACAAAC & 310 \\
\hline & Reverse & CGGTGGAGATTCTGGTTTGAAC & \\
\hline \multirow[t]{2}{*}{ MaPro 7} & Forward & CGGTGGAGATTCTGGTTTGAAC & 212 \\
\hline & Reverse & TTCGGCATCAACAGAATGGTAGATAC & \\
\hline \multirow[t]{2}{*}{ MaPro 8} & Forward & ACGTTITATTAGAAAGCCAAGGTAACC & 260 \\
\hline & Reverse & GGTATITCGTCGGTGTATTTGTAGCT & \\
\hline \multirow[t]{2}{*}{ MaPro 9} & Forward & GGGAAAAGGAAACTCTGCATTCG & 348 \\
\hline & Reverse & CATCCATTITCAGCAGTGTACAGTTCTAT & \\
\hline \multirow[t]{2}{*}{ MaPro 10} & Forward & CAGATAATGGCTCTACTAATATTGCACTC & 243 \\
\hline & Reverse & AGGGATCTTCACTTCCATTTGTGAATAC & \\
\hline \multirow[t]{2}{*}{ MaPro 11} & Forward & ATTTGGCTCAATGGAGGACCTG & 217 \\
\hline & Reverse & CAGCGGTATTATCATCAGTGTAAGAGT & \\
\hline \multirow[t]{2}{*}{ MaPro 12} & Forward & CCACCTACAAACCCCAAGGAGAC & 268 \\
\hline & Reverse & GCGAAAGAGTTGTCTTCCCAGACT & \\
\hline \multirow[t]{2}{*}{ MaPro 13} & Forward & CAGCTCTITTAACAGAAGGAGCTACAC & 352 \\
\hline & Reverse & TTTCTGAACTTCGGTATCCACCATA & \\
\hline \multirow[t]{2}{*}{ MaPro 14} & Forward & AGGGTATCTTCGAACAGCTCTTCG & 319 \\
\hline & Reverse & CATTGGGACAAGAGACTGAACAGTC & \\
\hline \multirow[t]{2}{*}{ MaPro 15} & Forward & AGCCTTGGAATGGAAATACTTTCGCTG & 319 \\
\hline & Reverse & CCAACACAGTATCCGTTAGAGCTACAG & \\
\hline \multirow[t]{2}{*}{ MaPro 16} & Forward & ACTCACGGATAGAACAATGCTCTTGC & 314 \\
\hline & Reverse & TTAAAGTGCTTGCGAGCCACTTCC & \\
\hline \multirow[t]{2}{*}{ MaPro 17} & Forward & TTGCAAGTTTCCTCTGGATTTGAATC & 327 \\
\hline & Reverse & TCCGTATATAAGTTCAATTGTGGCATC & \\
\hline \multirow[t]{2}{*}{$\beta$-tubulin } & Forward & GTATGATCATTGATAACGAAGCCCTCTACG & 323 \\
\hline & Reverse & TCTGGGATCGGCGGCGCACATCATG & \\
\hline
\end{tabular}

MaPro 5 with the cathepsin L protein of Uronema marinum (UmCatL, AAX51228), which is one of the most related scuticociliate species, were $30.7 \%, 35.9 \%, 35.6 \%$, $37 \%$ and $22.4 \%$, respectively. The MaPro 6 protein sequence contained a signal peptide, a propeptide $\mathrm{C} 1$ domain, and a peptidase $\mathrm{C} 1 \mathrm{~A}$ domain containing twelve conserved cysteine residues forming disulfide bonds and the "occluding loop" which is a specific feature of cathepsin B-like peptidases distinct from other $\mathrm{C} 1$ superfamily peptidases and had a $58.9 \%$ identity to the cathepsin B-like peptidase protein of $U$. marinum (Figure 1). We identified four different serine carboxypeptidase proteins and three different leishmanolysin family proteins in $M$. avidus. All four serine carboxypeptidase proteins contained a signal peptide, and three had a peptidase S10 domain, and one had a peptidase S28 domain that commonly exist in serine carboxypeptidase proteins. The leishmanolysin family proteins had a signal peptide, a 
Papain UmCatI MaPro1 Mapro2

MaPro3 MaPro4 Mapro5 MaPro7

HsCatB UmCatB MaPro6

Papain UmCatI

Mapro1 MaPro2 MaPro3

MaPro4

MaPro5

MaPro7

HsCatB

UmCatB

MaPro6

Papain UmCatI

Mapro1

MaPro2

MaPro3

Mapro4

Mapros

Mapro7

HsCatB

UmCatB

MaPro6

Papain UmCatI MaPro1

MaPro2

MaPro3

MaPro4

MaPro5

MaPro7

HsCatB

UmCatB

MaPro6

Papain UmCatI

MaPro1

MaPro2

MaPro3

MaPro4

MaPro5

Mapro?

HsCatB

UmCatB

MaPro6

Papain UmCatI

MaPro1

Mapro2

MaPro3

Mapro4

Mapro5

MaPro7

HsCatB

UmCat2

MaPro6

Signal peptide

I29/Propeptide C1 $E \quad R \quad F$ --MAMIPSISKLLFVAICLFVYMGLSFGPESIVGYSQNDLTSTERLIQL----MTSASTSVLSVGLAVLALSAFLLENGNT IITLQSSNTIDEVVYKS-------- ELLWKQQYKKNYNGEDE-QYREEVYK 70 $-------M K A A L I L S L L A L A S T A$ F FMMSNNQTT FLRASAATQDEVYKT-YVQWKSEFNQNFNGA-EDEYRENV 7066 ----------MKTVAVL ISLLAVS GIYLFASNSNNSL LSOAQSNEDIRIFQAYQQWKSDENKNTNGE-EDQMRLALFK 67 ---------MKTQIFLISLLTLSGETLFE $Q E Q D S Y R S L Q A T K D S X L F N T----$ EIQWKQQENQKYSKN-EEEYRFEAFK 65 --------MKNI I IFVVLVTFCVA $Q$ QAIGSQESHKKTM-------- ESMFAEKFEKIYETEQEFLHRFSVFE 56 -

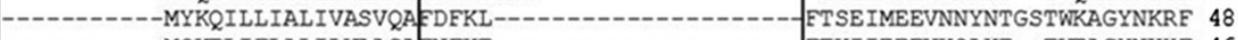
---------MQKTLIFLALILVAASP FNFKT---------------- ETKI IEEEVKQAKT--TWTAGYNKHE 46

\section{$N \quad I N \quad G N F D$}

DNLKYIDETNKKNNSYWL-GL-NVFADMSNDEE KEKYTGSIAGNYTTTELSYEEVLNDGDVN--------------- IPE 136 ENEQFVEE FNANNSFTL--GVENDFAAMTNEE RKAQFTSEI ISEGYNYQQVDRNVYEAVN-------------- APS 121 QNY I FVEETN-KGLEI PTVEL-NL FADLTNQEERQRHLGKQYRSEEEMKQNIKI PAFTNA---------------- NPS 131 SNYNY IQQ ENSEQTGSLRL GM-NVFA.AMENVEY IAKFVSGITHHSTELNIQEVSFDNVNAGD------------ LPT 130 DNYQFIEQHNAENS-DLVLGL-TPFAAMDNEEY RQNVLLRSRPSRQVPDSSIYASSGKD--------------- LPT 127 ENYNY IQKANAESK-NLVLGL-NQFA.AMSNEE KSLLSSKINVPNKSQKKSVQQTKETIQ------------- LPL 126 KNLEHMI THQDDDE-HGQY TV-TKPSDLSPEEEEKYLTLPSHKIDENQI PQQDEDGQYSIWDYLVGKKEEKIE-- MPK 131

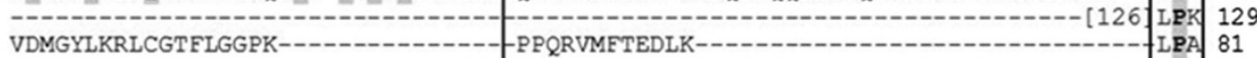
EGMSEDQIQAMMGTIATPV-------------ENWSYODIRNLMGLKOAPP-1

$$
\text { C \# } \quad \text { C } \quad \text { CC } \quad \text { C } \text { GCNGG }
$$

YVD----WRQKGAVTPVKNQGSCGSCWAFSAVVTIEGIIKIRTGN--LNEYSEQELLDCD-------RRSYGCNGGYPWSA. 204 GSVN---WVSKGAVQGVQNQGVCGSCWAFSAVCSLERLYKINTGK--LLSFSEQQLVSCE-------PKSYGCDGGWPEAA 190 SVD----WVAKGAVT PVVNQGNCGSCWAFGSVGALEGVYQVATGN--LI PLSQQQLVSCN----TNNGNEGCNGGLEVQA 201 SID----WVKKGAVAPVENQGQCGSCWAFSTKEGLEGVYAIQSGS--MVVLSAQQLVSCS----TQN--LGCNGGDPMTA 198 SID----WVAKGAVYATQNQGHCGSCWAFATIGGLQGLRQISTGK--LELLSAQQIT SCVDKRFLDDYTQGCGGGEARYA 201 SVD----WVQAGAVTEAGEQGFCDAGYAFASSASVEGARFIKQNV--LEKLSKQQLISCIR----FPLSLGCGGGNAENA. 196 NFD----WRQKNVITEVKAQSTCGSCWAFTTAAMIESQIAIKYGK--LENLSEQQLIDCD------TINDGCGGGLMTDA 199 EFS----WEEY--INEPVQQRDCGSCYAIATSEMLSTRLKIHHKE--DVRISAQHSLDCN-------FYNQGCDGGYGFLV 203 SFDAREQWPQCPTIKE IRDQ GSCGSCWAFGAVEAISDRICI ITTNAHVSVEVSAEDLLTCC----GSMCGDGCNGGYPAEA 157 SFDLREAYPKCESLQQVRDOSNCGSCWAFGTVEAISDRICIASGQKDQTRISSENLLSCCRG--TFACGMGCNGGYTAGA 166 SFDPREFWPRCESIKE IRDQANCGSCWAFGSAEAMSDRICIASGQKVQTRISTENLLSCCVG--MFACGNGCNGGFIEGA 164

C $\quad$ C C C C $\quad c \quad c \quad c$

LQLVAOYG-IHYRNTY------FAYSATHG-LESSASY--------------------PYVQQKN--GKTASCQYNSSKATKGINKS----YKNVAANSPD 242 YAYTQQYG-IQTAASY--------------------PYTSGTT--GLNGKCHYNSSDVVYKNTGY----ETLPLRDPVA 253 YAYTQKNG-IVAEDSY-----------------------PYVSGK---GQVPSCNENQSDIVYKNSGQ-----VKVANSOTVT 249 YMYTAING-IETWENY--------------------PYVDGDDSSTVASPCKYNQKNAVFYNEG-----VSFIRPNDVQ 254 ITYMNQNG-ISTELDY----------------------PFVQQQQ--TRELPCDKNKIKPVSYQSGT----LVTIQANNPN 248 YKELOSTGGLQSRNDY---------------------GEYLNRK--GQ---CHFEKSKIKGKIVNY----YQIGK-DEYE 248 SKFASEYE-MVREECH--------------------PYKAVNG--RCADSCDVSKEKKTYKVSDYKYLGGAYGKSSERV 259 WNFWTRKG-LVSGGLY-----ESHVGCRPYSI PPCEHHVNGSRPPCTGEGD--TPKCSKICEPGY-SPTYKQDKHYGYNS 228 WNYYVKTG-LVSGNLYTDDNQNSKTECQPYSFPPCSHHVQGEYQACTDLPQFNTPKCYTECNSQYTQNSYEQDLHKGVSS 245 WSYFQKTG-LVTGNLY-----EENKYCQPYAFPPCDHHVQGQYSPCEGMQK--TPKCVKQCNSEY-NVPYEQDIHKGQST 235

$$
\mathrm{C}
$$

\section{\#}

\section{\#}

SIANOPVSVVLEAAGKDFOLYRGG--------IFVGPCG---NKVDHAVAAVGYG-----PNYILIKNSWGTGWG 315 SIYNALVKOPLSI LVDASSSVFQHYGS---------GVINSTACG---TTLNHAINVVGYS------GSVWTLRNSWGTTWG 306 -KEAGLARSPLSAGINGGSIFFQLYNGK-------SVLNNKGCT---AELNHSVTLVGYN-NDAQVPYWTIKNSWGNGWG 321 NIQKAVQNNPATIEIAASSIVFQLYKS--------GVLTSTACG---TALDHGVLLTGYN-TAGSEPYWTIKNSWGTGWG 317 GIKEKLNOOPLTIAVDAGSIYFOLYKN---------GVINTDKCG---IELNHAILLVGYN-LEGETPYWTVCNSWGTGWG 322 EMKQALSKQPIVASIASGSLAFQLYKS--------GVISNCHGD---TDINHYVLLVGYN-DLENS--WT FKNSWGQTWG 314 IQKELFLNGPVAVGINGR--FLQFYDG--------GILNNDKCD---ERINHAVI IVRYGENEDGTKYWI IKNQWGKQWG 315 MMEEMMENGPIVVSFE PAYDFMYYDSGIYHSVDAEKWIKNHDSQPVWEKVDHSVLAYGWG-EEEGQKYWKVINSWGSNWG 288 YSVSNSEKDIMAE IYKNGPVEGAFSVYSDFLLYKSGVYQHVTGE---MMGGHAIRI LGWG-VENGTPYWLVANSWNTDWG 304 YSVPKSEEQIKAEIYQYGSTTASENVYSDFLTYSSGVYQNTSGS---YMGGHAIKMLGWG-VENGTPYWLCANSWNSSWG 321 YKVKASVEQIQAEIMTNGPVTAGITVYEDFLTYTGGVYQHTTGS---YAGGHAIKILGWG-VENGTPYWLCANSWNEDWG 311

$$
\text { c }
$$

ENGYIRIKRGTGN-SYGVCGLYTSSFYPVKN 345

Peptidase C1A

EKGYARVQYST--G-AGYCGMNRSASYPTN 333

DQGFMRIYKSMEKGIDGVCGIQIEATGPSYQNV 355

QSGYANILISGNG--KGTCGVQQYVAYPLY 346

NNGFGNIAITEGN---GVCGINMQVDYPTSVTQSQ 355

MQGYAKITIEQGN---GLCGINMDVSHPKL 342

NDGYFKLIRGQKK-----CGVHTYASIAFVE 342

ENGTFRIRRGTDE-----SHIESMGEAATPIVINKY 320

DNGFFKILRGQDH-----CGIESEVVAGI PRTDQYWEKII

ENGFFKILRGSNE-----CGIESGMVAGFVPGQQ 350

LGGLFKILRGVNE-----CGIESQVVAGLV 337

Figure 1 (See legend on next page.) 
(See figure on previous page.)

Figure 1 Multiple alignment of the deduced amino acid sequences of Miamiensis avidus cysteine peptidases. The deduced amino acid sequences of Miamiensis avidus cysteine peptidases MaPro 1 to - MaPro 7 were aligned with Papain (the type peptidase of C1A superfamily, GenBank: AAB02650), Uronema marinum cathepsin L-like protein (UmCatL, GenBank: AAX51228), Homo sapiens cathepsin B protein (HsCatB, GenBank: AAH10240) and Uronema marinum cathepsin B protein (UmCatB, GenBank: AAR19103). The signal peptide, I29 (Inhibitor 29)/

Propeptide, Peptidase C1A domains are boxed. Conserved signatures of cathepsin L family proteins (ERFNIN and GNFD) with slight modifications in I-29 peptide of the cathepsin L-like proteins (MaPro 1- MaPro 5) are highlighted in bold, italic, grey shaded and indicated by ERFNIN and GNFD above the alignment. The catalytic triad residues ( $\mathrm{C}, \mathrm{H}$ and $\mathrm{N}$ ) are marked in bold, grey shaded and indicated by sharp (\#). Conserved proline residues at position 2 of the mature proteins are indicated by asterisk $\left(^{*}\right)$ and cysteine residues forming disulphide bonds are in bold, grey shaded and indicated by $\mathrm{C}$ above the alignment. $\mathrm{S}_{2}$ subsite determining enzyme substrate specificity is indicated by a black vertical arrow above the alignment. The predicted 'occluding loop', which is the specific feature of cathepsin B-like peptidases, is presented in only MaPro 6 and is indicated with a black thick underline.

peptidase M8 domain, and a different number of epidermal growth factor (EGF)-like domains and furine-like repeats. As the individual lengths of the proteins were varied (Table 1), common peptidase M8 domains were aligned for comparative purposes with other reported leishmanolysin family protein sequences of similar protozoa (Figure 2). As shown in Figure 2, the HEXXH motif and cysteine residues conserved in other metallopeptidase proteins were present [22].

\section{Real-time reverse transcriptase polymerase chain reaction (RT-PCR) of peptidase genes}

The relative level of peptidase genes expression was analyzed by quantitative RT-PCR using cDNA prepared from $M$. avidus RNA grown under the different culture conditions. As shown in Table 3, the MaPro 4, MaPro 7, MaPro 14, and MaPro 17 genes, which corresponded with a cathepsin L-like cysteine peptidase, a cathepsin C-like cysteine peptidase, a leishmanolysin-like peptidase and a peptidase family M49 protein gene, showed more than 2-fold increased expression in the cell-fed ciliates compared with that in the starved ciliates. Two leishmanolysin-like peptidases, MaPro 15 and MaPro 16, showed detectable $\mathrm{Ct}$ values only in the cell-fed ciliates during our RT-PCR process (Table 3 ).

\section{Discussion}

Scuticociliatosis, causing severe mortality in South Korea, has been considered one of the most serious fish diseases than any other countries [6,7]. Although several reports have revealed that some chemotherapeutics showed effective scuticocidal activities in vitro [25-27], finding effective chemotherapeutics is still remained to be difficult in vivo. Therefore, efficient vaccine development is urgently to prevent diseases. Several studied have attempted to develop vaccines using whole cells and have shown some positive results by obtaining good protection against scuticociliate infection following vaccination [28-30]. However, as there are some limitations for in vitro mass and economic culture of scuticociliates for commercial use, subunit vaccines should be developed with development of cost-effective methods of antigens. Selecting suitable target antigens that can induce effective protective responses may be the most important factor to develop effective subunit vaccines. Among scuticociliate antigens, the crucial roles of peptidases in infection of host fish have been already reported by previous studies [8-12,31].

In the present study, M. avidus were starved for at least 1 month by inoculation in the filtered seawater without any additional nutrients and cells. Similar to what occurs during the free-living stage, these starved ciliates may lose their ability to destroy fish tissue due to a reduction in protease activities they need. Quantitative RT-PCR was performed to investigate mRNA expression of the identified peptidase genes in relation with the cell-feeding parasitic stage of $M$. avidus. The results showed that two cysteine peptidases, a leishmanolysinlike peptidase and a peptidase family M49 protein genes were up-regulated more than 2-fold in the cell-fed ciliates than in the starved ciliates. Among them, one cysteine peptidase gene (MaPro 4) and one leishmanolysin-like peptidase gene (MaPro 14) showed 100-fold higher expression in the cell-fed ciliates. Expression of two other leishmanolysin-like peptidase genes (MaPro 15 and MaPro 16) was detected only in the cell-fed ciliates.

The differential expression of the cysteine peptidases in the cell-fed ciliates might be an important part of $M$. avidus pathogenesis as shown in previous studies [8-12]. Many parasite cysteine peptidases and their important roles in pathogenesis have been well documented in a variety of parasites and inhibitors of cysteine peptidases have been developed for anti-parasitic chemotherapy, as cysteine peptidase inhibitors can selectively inhibit parasite peptidases without untoward toxicity to the host [32-36]. In this study, we cloned seven different cysteine peptidases genes and two of them (MaPro 4 and MaPro 7) were differentially up-regulated in the cell-fed ciliates. We obtained the mRNA sequences of three leishmanolysinlike family proteins containing the metalloprotease M8 domain and found differential mRNA expression in the cell-fed ciliates. Leishmanolysin, which is also known as 


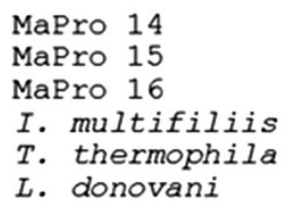

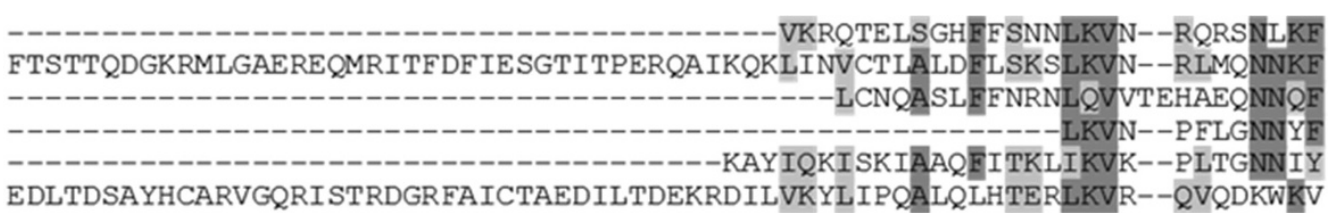

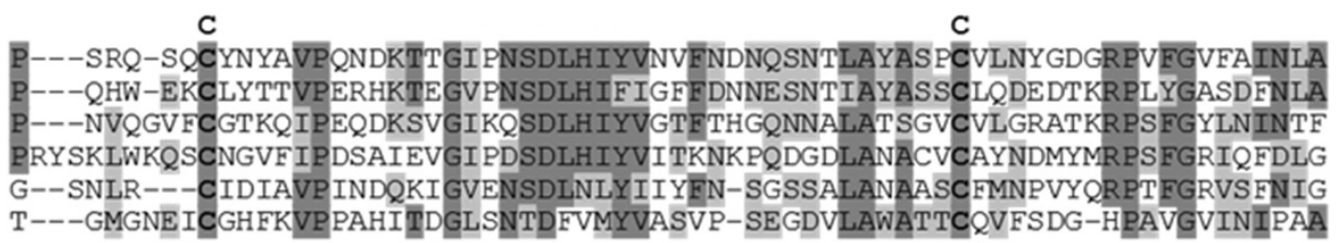

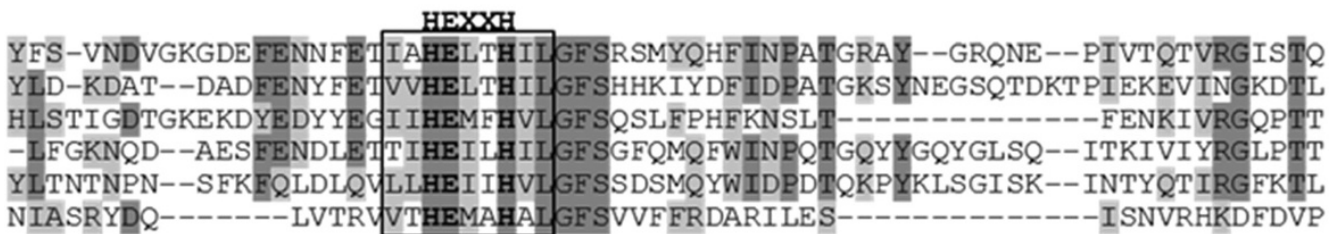

C WITTPKV̄KQLARDYYRCPSAIGMQLENQGGSGSAYSHWERT ILENDYM̄TĀSAIGHDĀVISRFTLALLEDS WVTTPKV QQMAREHY GCPTIKGIQLENDYGGGSRNSHWERSTFENEYMNAMHSGHDAAI SKFT FALLEDS WVTSPKVKEVARKHFNCTDAI GMQLENYNGDNNENQHWERVLLNNELMTGNFKRPFGLVSI FTWALLEDS LVMTKNILQTARKYYACPNMEGMQLENEGGSGSLGSHWEQLIVQNEMMMÄSDVITDÄLLSVLTIALLRDT ILTSKNVTDIARKHYNCSQIIGMQI ENQGGSGSÄGSHWERTVIMNELMTAQQVSI GATLSQFT IALLKDT VINSSTAVAKAREQYGCGTLEYLEMEDQGGAGSAGSHIKMRNAQDELMAP--ASDAGYYSALTMAIFQDL

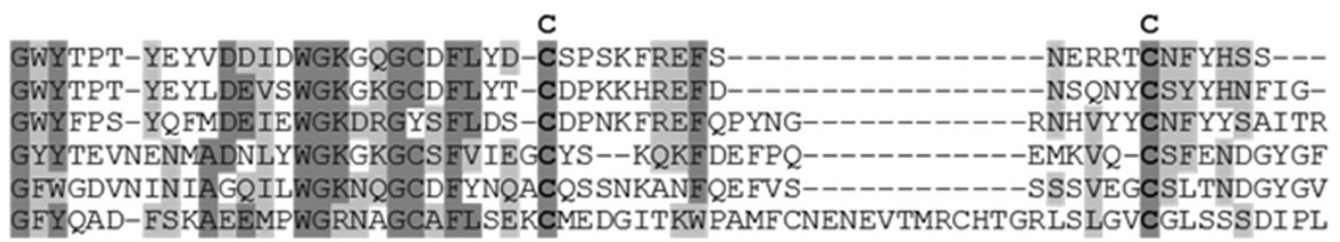

\section{YHSIPDDEEERRKQTCHAFQ \\ SHQLGETQGECQIGTDYL-- \\ PETTPYFDKCLMKDIYGNKL \\ GINDGFSDNCYYIQPYSNML \\ PPYWQYFTDPLLAGISAFMD}

Figure 2 Multiple sequence alignment of peptidase M8 domains of the Miamiensis avidus leishmanolysin family proteins. The peptidase M8 domains of M. avidus leishmanolysin family proteins MaPro 14 - MaPro 16 were aligned with the previously deposited protozoan sequences in protein databases. The zinc-binding signature, HEXXH motif conserved in many kinds of metallopeptidases is shown in bold and in square box, and cysteine residues are presented in bold. The GenBank accession numbers of aligned leishmanolysin family proteins of Ichthyophtirius multifiliis, Leishmania donovani and Tetrahymena thermophila are EGR30431, XP_001024633 and AAA29244, respectively.

the gp63 protein, is a metalloprotease found in protozoan parasites including Leishmania and Trypanosoma. This protein is the most abundant cell surface protein during the promastigote stage of the parasite and is attached to the membrane by a glycosylphosphatidylinositol anchor [37-40]. The protective effects of gp63 immunization have been recently demonstrated using various vaccine formulations by many researchers [41,42]. In fish pathogenic haemoflagellates Cryptobia spp., metallopeptidase activity was only found in the pathogenic strain of C. salmositica, its activity decreased significantly with long-term in vitro culture, and the purified metallopeptidases could lyse fish red blood cells [43-45]. Moreover, metallopeptidase activities could be neutralized by either a monoclonal antibody or a natural anti-peptidase or the antibody against the DNA vaccines [46-48].

Recent technological advances in whole genome sequence analyses and comparative genomic analyses have revealed that there are more than 90 peptidase homologs in a single organism such as Plasmodium falciparum, Tetrahymena thermophila and Ichthyophthirius multifiliis [49-51]. In protozoa, 254, 578, 480 and 95 peptidase 
Table 3 Real time RT-PCR analysis of peptidase genes in Miamiensis avidus under the different culture conditions

\begin{tabular}{|c|c|c|c|c|}
\hline \multirow[t]{2}{*}{ Name of clone } & \multicolumn{2}{|c|}{ Mean $\mathrm{Ct}^{\mathrm{a}}$ value $\left(\mathrm{SD}^{\mathrm{b}}\right)$} & \multicolumn{2}{|c|}{ Fold increase in expression $\left(2^{-\Delta \Delta C t}(S D)\right)$} \\
\hline & Cell-free culture & Cell-feeding culture & Cell-free culture & Cell-feeding culture \\
\hline MaPro 1 & $28.48(0.51)$ & $22.67(0.32)$ & $1.05(0.40)$ & $1.01(0.22)$ \\
\hline MaPro $2^{* *}$ & $25.38(0.24)$ & $21.25(0.12)$ & $1.01(0.16)$ & $0.31(0.03)$ \\
\hline MaPro 3 & $27.43(0.34)$ & $22.11(0.10)$ & $1.02(0.23)$ & $0.71(0.05)$ \\
\hline MaPro $4^{* *}$ & $34.96(0.28)$ & $21.95(0.24)$ & $1.02(0.20)$ & $147.58(24.89)$ \\
\hline MaPro 5 & $33.19(0.44)$ & $29.71(0.63)$ & $1.03(0.30)$ & $0.21(0.08)$ \\
\hline MaPro $6^{* *}$ & $23.93(0.36)$ & $20.01(0.19)$ & $1.02(0.27)$ & $0.27(0.04)$ \\
\hline MaPro $7^{*}$ & $33.61(0.31)$ & $25.72(0.11)$ & $1.01(0.22)$ & $4.19(0.33)$ \\
\hline MaPro $8^{* *}$ & $26.94(0.21)$ & $24.11(0.31)$ & $1.01(0.14)$ & $0.13(0.03)$ \\
\hline MaPro $9^{*}$ & 29.33(0.58) & $26.79(0.58)$ & $1.05(0.42)$ & $0.11(0.04)$ \\
\hline MaPro 10 & $32.67(1.44)$ & $26.44(0.29)$ & $1.29(0.86)$ & $1.34(0.27)$ \\
\hline MaPro 11 & $30.26(1.30)$ & $25.09(0.25)$ & $1.24(0.79)$ & $0.64(0.11)$ \\
\hline MaPro $12^{* *}$ & $25.57(0.08)$ & $22.90(0.29)$ & $1.00(0.06)$ & $0.11(0.02)$ \\
\hline MaPro $13^{*}$ & $34.37(0.34)$ & $31.15(1.30)$ & $1.02(0.22)$ & $0.21(0.16)$ \\
\hline MaPro $14^{* *}$ & $32.51(0.41)$ & $19.37(0.01)$ & $1.03(0.27)$ & $159.78(1.40)$ \\
\hline MaPro 15 & $N / A^{c}$ & $31.12(0.76)$ & & \\
\hline MaPro 16 & N/A & $31.52(0.57)$ & & \\
\hline MaPro $17^{*}$ & $34.68(0.77)$ & $26.87(0.32)$ & $1.10(0.54)$ & $4.04(0.84)$ \\
\hline$\beta$-tubulin & $23.37(0.45)$ & $17.55(0.22)$ & & \\
\hline
\end{tabular}

${ }^{a} \mathrm{Ct}$ : Cycle threshold, ${ }^{\mathrm{b}} \mathrm{SD}$ : standard deviation, ${ }^{\mathrm{C}} \mathrm{N} / \mathrm{A}$ : No detectable Ct value was obtained within 40 cycles, $^{*}:$ Significant differences $\mathrm{P}<0.05,{ }^{* *}:$ Significant differences $\mathrm{P}<0.005$.

genes have been identified in Ichthyophthrius multifiliis, Paramecium tetraurelia, Tetrahymena thermophile, and Plasmodium falciparum, respectively [51]. Like other parasites, $M$. avidus may express many peptidase proteins to undergo various biological processes including parasite survival and pathogenesis. In this study, we obtained 17 different peptidase genes from a M. avidus cDNA library by ESTs sequence screening, and the results of differential mRNA expression related to pathogenesis were also obtained. Based on the analysis of structurally conserved regions and motifs presented in the deduced amino acid sequences of each peptidase proteins, five cathepsin L-like cysteine peptidases, one cathepsin B-like cysteine peptidase, one cathepsin C-like cysteine peptidase, four serine carboxypeptidase, a eukaryotic aspartyl protease family protein, an ATPdependent metalloprotease FtsH family protein, three leishmanolysin family proteins, and a peptidase family M49 protein were identified although there were some structurally differences with previously reported similar proteins. Although the number of identified peptidase genes obtained from this study was relatively lower than expected, this is the first report of cloning and mRNA expression of peptidase gene homologs as important virulence factors in $M$. avidus. Moreover, the information of exact protein sequence obtained from this study could help to perform futher studies to develop specific inhibitors.
We are currently performing studies on the actual activities using recombinant proteins of cloned peptidase genes to understand whether these proteins are biologically active at the protein level. We will further analyze of $M$. avidus genome using large scale-genome analysis techniques to identify more peptidase sequences, and will perform combined research of transcriptional analysis and enzymatic activities of each peptidase proteins.

\section{Conclusions}

In conclusion, the genetic information obtained from this study could help to design specific vaccine formulations and inhibitors of peptidases to prevent and control of fish scuticociliatosis caused by $M$. avidus, although further studies to elucidate the exact roles of these peptidases should be conducted.

\section{Competing interests}

The authors declare that they have no competing interests.

\section{Authors' contributions}

EHL contributed to the design of the study, performing experiments, data analysis and preparation of the manuscript. JSS contributed to the design of the study and advised on data analysis and review of the manuscript. SHW and EJJ participated in data collection and experimental procedure. SHJ, MAP, JWK, KHK involved with the review of the manuscript. All authors read and approved the final manuscript. 


\section{Acknowledgements}

This study was supported by a research fund of the National Fisheries Research and Development Institute (NFRDI, RP-2012-AQ-062), Republic of Korea.

\section{Author details}

${ }^{1}$ Pathology Division, National Fisheries Research \& Development Institute (NFRDI), 152-1, Haean-Lo, Gijang-Up, Gijang-Gun, Busan 619-705, South Korea. ${ }^{2}$ Aquatic Life Disease Control Division, NFRDI, 152-1, Haean-Lo, Gijang-Up, Gijang-Gun, Busan 619-705, South Korea. ${ }^{3}$ Department of Aquatic Life Medicine, Pukyong National University, 599-1 Daeyondong, Namgu, Busan 608-737, South Korea. ${ }^{4}$ Institute of Fisheries Sciences, Pukyong National University, 295, Dongbaek-ri, Ilgwang-myeon, Gijang-gun, Busan 619-911, South Korea.

Received: 4 May 2012 Accepted: 19 December 2012 Published: 11 January 2013

\section{References}

1. McKerrow JH, Sun E, Rosenthal PJ, Bouvier J: The proteases and pathogenicity of parasitic protozoa. Annu Rev Microbiol 1993, 47:821-853.

2. Que X, Reed SL: The role of extracellular cysteine proteinases in pathogenesis of Entamoeba histolytica invasion. Parasitol Today 1997, 13:190-194.

3. Rosenthal PJ: Proteases of protozoan parasites. Adv Parasitol 1999, 43:105-159.

4. Jime'nez JC, Uzcanga G, Zambrano A, Di Prisco MC, Lynch NR: Identification and partial characterization of excretory/secretory products with proteolytic activity in Giardia intestinalis. J Parasitol 2000, 86:859-862.

5. Klenmba M, Goldberg DE: Biological roles of proteases in parasitic protozoa. Annu Rev Biochem 2002, 71:275-305.

6. Kim SM, Cho JB, Kim SK, Nam YK, Kim KH: Occurrence of scuticociliatosis in olive flounder Paralichthys olivaceus by Philasterides dicentrarchi (Ciliophora: Scuticociitida). Dis Aquat Organ 2004, 62:233-238.

7. Jung SJ, Kitamura S, Song JY, Oh MJ: Miamiensis avidus (Ciliophora: Scuticociliatida) causes systemic infection of olive flounder Paralichthys olivaceus and is a senior synonym of Philasterides dicentrarchi. Dis Aquat Organ 2007, 73(3):227-234

8. Paramá A, Iglesias R, Alvarez MF, Sanmartn ML, Leiro J: Chemotactic responses of the fish-parasitic scuticociliate Philasterides dicentrarchi to blood and blood components of the turbot Scophthalmus maximus, evaluated using a new microplate multiassay. J Microbiol Methods 2004, 58:361-366.

9. Paramá A, Iglesias R, Alvarez MF, Leiro J, Ubeira FM, Sanmartín ML: Cysteine proteinase activities in the fish pathogen Philasterides dicentrarchi (Ciliophora: Scuticociliatida). Parasitology 2004, 128:541-548.

10. Paramá A, Castro R, Arranz JA, Sanmartín ML, Lamas J, Leiro J: Scuticociliate cysteine proteinases modulate turbot leucocyte functions. Fish Shellfish Immunol 2007, 23(5):945-956.

11. Paramá A, Castro R, Lamas J, Sanmartín ML, Santamarina MT, Leiro J: Scuticociliate proteinases may modulate turbot immune response by inducing apoptosis in pronephric leucocytes. Int J Parasitol 2007, 37:87-95.

12. Piazzon C, Lamas J, Leiro M: Role of scuticociliate proteinases in infection success in turbot, Psetta maxima (L.). Parasite Immunol 2011, 33:535-544.

13. Lee $\mathrm{EH}, \mathrm{Kim} \mathrm{KH}$ : Identification of differentially expressed genes in parasitic phase Miamiensis avidus (Ciliophora: Scuticociliatia) using suppression subtractive hybridization. Dis Aquat Organ 2011, 94:135-142

14. Giulietti A, Oververgh L, Valckx D, Decallonne B, Bouillon R, Mathieu C: An overview of real-time quantitative PCR: applications to quantify cytokine gene expression. Methods 2001, 25:386-401.

15. Livak KJ, Schmittgen TD: Analysis of Relative Gene Expression Data Using Real-Time Quantitative PCR and the $2^{-\Delta \Delta C T}$ Method. Methods 2001, 25:402-408.

16. Jesudhasan PR, Tan CW, Hontzeas N, Woo PT: A cathepsin L-like cysteine proteinase gene from the protozoan parasite, Cryptobia salmositica. Parasitol Res 2007, 100:881-886.

17. Herrmann L, Erkelenz M, Aldag I, Tiedtke A, Hartmann MW: Biochemical and molecular characterisation of Tetrahymena thermophila extracellular cysteine proteases. BMC Microbiol 2006, 6:19.

18. Jousson O, Di Bello D, Donadio E, Felicioli A, Pretti C: Differential expression of cysteine proteases in developmental stages of the parasitic ciliate Ichthyophthirius multifiliis. FEMS Microbiol Lett 2007, 269:77-84.
19. Ahn SJ, Seo JS, Kim MS, Jeon SJ, Kim NY, Jang JH, Kim KH, Hong YK, Chung $\mathrm{JK}$, Lee $\mathrm{HH}$ : Cloning, site-directed mutagenesis and expression of cathepsin L-like cysteine protease from Uronema marinum (Ciliophora: Scuticociliatida). Mol Biochem Parasitol 2007, 156:191-198.

20. Lim SU, Seo JS, Kim MS, Ahn SJ, Jeong HD, Kim KH, Park NG, Kim JK, Chung $\mathrm{JK}$, Lee HH: Molecular cloning and characterization of Cathepsin B from a scuticociliate, Uronema marinum. Comp Biochem Physiol B Biochem Mol Biol 2005, 142:283-292.

21. Sajid M, McKerrow JH: Cysteine proteases of parasitic organisms. Mol Biochem Parasitol 2002, 120:1-21.

22. Jiang W, Bond JS: Families of metalloendopeptidases and their relationships. FEBS Lett 1992, 312:110-114.

23. Karrer KM, Peiffer SL, DiTomas ME: Two distinct gene subfamilies within the family of cysteine protease genes. Proc Natl Acad Sci USA 1993, 90:3063-3067.

24. Vernet T, Berti PJ, DeMontigny C, Musil R, Tessier DC, Menard R, Magny MC, Storer AC, Thomas DY: Processing of the papain precursor. The ionization state of a conserved amino acid motif within the Pro region participates in the regulation of intra-molecular processing. J Biol Chem 1995, 270:18038-10846.

25. Iglesias R, Paramá A, Álvarez MF, Leiro J, Sanmartín ML: Antiprotozoals effective in vitro against the scuticociliate fish pathogen Philasterides dicentrarchi. Dis Aquat Organ 2002, 49:191-197.

26. Quintela JM, Peinador C, González L, Iglesias R, Paramá A, Álvarez F, Sanmartín ML, Riguera R: Piperazine N-substituted naphthyridines, pyridothienopyrimidines and pyridothienotriazines: new antiprotozoals active against Philasterides dicentrarchi. Eur J Med Chem 2003, 38:265-275.

27. Paramá A, Piazzon MC, Lamas J, Sanmartín ML, Leiro J: In vitro activity of the nonsteroidal anti-inflammatory drug indomethacin on a scuticociliate parasite of farmed turbot. Vet Parasitol 2007, 48:318-324.

28. Sitjà-Bobadilla A, Palenzuela O, Alvarez-Pellitero $P$ : Immune response of turbot, Psetta maxima (L.) (Pisces: Teleostei), to formalin-killed scuticociliates (Ciliophora) and adjuvanted formulations. Fish Shellfish Immunol 2007, 24:1-10.

29. Sanmartín ML, Paramá A, Castro R, Cabaleiro S, Leiro J, Lamas J, Barja لl: Vaccination of turbot, Psetta maxima (L.), against the protozoan parasite Philasterides dicentrarchi: effects on antibody production and protection. J Fish Dis 2008, 31:135-140.

30. Lee EH, Kim KH: Immobilization antigen-independent protection of olive flounder (Paralichthys olivaceus) against Philasterides dicentrarchi (Ciliophora: Scuticociliatia) infection. Aquaculture 2008, 279:211-213.

31. Lee EH, Kim CS, Cho JB, Ahn KJ, Kim KH: Measurement of protease activity of live Uronema marinun (Ciliata: Scuticociliatida) by fluorescence polarization. Dis Aquat Organ 2003, 54:85-88.

32. Sajid M, MeKerrow JH: Cysteine proteases of parasitic organisms. Mol Biochem Parasitol 2002, 120:1-21.

33. Mckerrow JH, Engel JC, Caffrey CR: Cysteine protease inhibitors as chemotherapy for parasitic infections. Bioorg Med Chem 1999, 7:639-644

34. Engel JC, Doyle PS, Hsieh I, McKerrow JH: Cysteine protease inhibitors cure an experimental Trypanosoma cruzi infection. J Exp Med 1998, 188:725-734.

35. McKerrow JH, Rosenthal PJ, Swenerton R, Doyle P: Development of protease inhibitors for protozoan infections. Curr Opin Infect Dis 2008, 21:668-672.

36. Atkinson HJ, Babbitt PC, Sajid M: The global cysteine peptidase landscape in parasites. Trends Parasitol 2009, 25:573-581.

37. Bouvier J, Etges RJ, Bordier C: Identification and purification of membrane and soluble forms of the major surface protein of Leishmania promastigotes. J Biol Chem 1985, 260:15504-15509.

38. Bouvier J, Bordier C, Vogel H, Reichelt R, Etges R: Characterization of the promastigote surface protease of Leishmania as a membrane-bound zinc endopeptidase. Mol Biochem Parasitol 1989, 37:235-245.

39. Etges R, Bouvier J, Bordier C: The major surface protein of Leishmania promastigotes is a protease. J Biol Chem 1986, 261:9098-9101.

40. Etges R, Bouvier J, Bordier C: The major surface protein of Leishmania promastigotes is anchored in the membrane by a myristic acidlabeled phospholipid. EMBO J 1986, 5:597-601.

41. Mazumder S, Maji M, Das A, Ali N: Potency, efficacy and durability of DNA/ DNA, DNA/protein and protein/protein based vaccination using gp63 against Leishmania donovani in BALB/c mice. PLoS One 2011, 6:e14644.

42. Bhowmick S, Ravindran R, Ali N: gp63 in stable cationic liposomes confers sustained vaccine immunity to susceptible BALB/c mice infected with Leishmania donovani. Infect Immun 2008, 76:1003-1015. 
43. Zuo $X$, Woo PTK: Proteases in pathogenic and nonpathogenic haemoflagellates, Cryptobia spp. (Sarcomastigophora: Kinetoplastida), of fishes. Dis Aquat Organ 1997, 29:57-65.

44. Uo X, Woo PTK: Purified metalloprotease from the pathogenic haemoflagellate, Cryptobia salmositica, and its in vitro proteolytic activities. Dis Aquat Organ 1997, 30:177-185.

45. Woo PT: Immunological and therapeutic strategies against salmonid cryptobiosis. J Biomed Biotechnol 2010, :Article ID 341783.

46. Zuo X, Woo PTK: In vivo neutralization of Cryptobia salmositica metalloprotease by a2-macroglobulin in the blood of rainbow trout Oncorhynchus mykiss and in brook charr Salvelinus fontinalis. Dis Aquat Organ 1997, 29:67-72.

47. Zuo X, Woo PTK: Natural anti-proteases in rainbow trout, Oncorhynchus mykiss and brook charr, Salvelinus fontinalis and the in vitro neutralization of fish a2-macroglobulin by the metalloprotease from the pathogenic haemoflagellate, Cryptobia salmositica. Parasitology 1997, 114:375-382.

48. Tan CW, Jesudhasan PRR, Woo PTK: Towards a metalloprotease-DNA vaccine against piscine cryptobiosis caused by Cryptobia salmositica. Parasitol Res 2008, 102:265-275.

49. Wu Y, Wang $X$, Liu $X$, Wang Y: Data-mining approaches reveal hidden families of proteases in the genome of malaria parasite. Genome Res 2003, 13:601-616.

50. Eisen JA, Coyne RS, Wu M, Wu D, Thiagarajan M, Wortman JR, Badger JH, Ren Q, Amedeo P, Jones KM, Tallon $\sqcup$, Delcher AL, Salzberg SL, Silva JC, Haas BJ, Majoros WH, Farzad M: Macronuclear genome sequence of the ciliate Tetrahymena thermophila, a model eukaryote. PLoS Biol 2006, 4:e286.

51. Coyne RS, Hannick L, Shanmugam D, Hostetler JB, Brami D, Joardar VS, Johnson J, Radune D, Singh I, Badger JH, Kumar U, Saier M, Wang Y, Cai H, Gu J, Mather MW, Vaidya AB, Wilkes DE, Rajagopalan V, Asai DJ, Pearson CG, Findly RC, Dickerson HW, Wu M, Martens C, Van de Peer Y, Roos DS, Cassidy-Hanley DM, Clark TG: Comparative genomics of the pathogenic ciliate Ichthyophthirius multifiliis, its free-living relatives and a host species provide insights into adoption of a parasitic lifestyle and prospects for disease control. Genome Biol 2011, 12:R100.

doi:10.1186/1746-6148-9-10

Cite this article as: Seo et al.: Molecular cloning and expression analysis of peptidase genes in the fish-pathogenic scuticociliate Miamiensis avidus. BMC Veterinary Research 2013 9:10.

\section{Submit your next manuscript to BioMed Central and take full advantage of:}

- Convenient online submission

- Thorough peer review

- No space constraints or color figure charges

- Immediate publication on acceptance

- Inclusion in PubMed, CAS, Scopus and Google Scholar

- Research which is freely available for redistribution 